\title{
Cultivating Cross-Cultural Learning and Collaboration Among Special Educators Engaged in International Service-Learning
}

\section{Amy Rose}

Western Carolina University, USA

Melissa Snyder

Western Carolina University, USA

Amy Murphy-Nugen

Western Carolina University, USA

Gayle Maddox

Western Carolina University, USA

Carol Isaac MacKusick

Western Carolina University, USA

Bontle Molefe

Botswana Society for the Deaf, USA

\section{Recommended Citation}

Rose, A., Snyder, M., Murphy-Nugen, A., Maddox, G., MacKusick, C. I., \& Molefe, B. (2021). Cultivating cross-cultural learning and collaboration among special educators engaged in international servicelearning. International Journal of Research on Service-Learning and Community Engagement, 9(1). Article 10. https://doi.org/10.37333/001c.31307 


\section{Cultivating Cross-Cultural Learning and Collaboration Among Special Educators Engaged in International Service-Learning}

Amy Rose, Melissa Snyder, Amy MurphyNugen, Gayle Maddox, Carol Isaac MacKusick, and Bontle Molefe

The purpose of this project was to explore the influence of international service-learning on the personal and professional development of future special educators and speech-language pathologists. The service-learning students engaged in educational site visits, presentation of workshops, cultural activities, and interprofessional exchange in Botswana. Students completed surveys at the end of the trip and then participated in a focus group interview nine months after the study abroad course was completed. Findings from a qualitative content analysis revealed five emerging themes: openmindedness, boundary spanning, cultural humility, skill development, and confidence. Implications for cross-cultural collaboration are discussed along with consideration for predeparture activities, high-impact educational practices, and student confidence in achieving professional skills standards.

Keywords: Botswana, special education, communication disorders, speech-language pathology, international service-learning, study abroad

\section{Cultivando el aprendizaje intercultural y la colaboración entre los educadores de la educación especial participando en el aprendizaje de servicio internacional}

\author{
Amy Rose, Melissa Snyder, Amy Murphy- \\ Nugen, Gayle Maddox, Carol Isaac \\ MacKusick, y Bontle Molefe
}

El objetivo de este proyecto fue explorar la influencia del aprendizaje de servicio internacional en el desarrollo personal y profesional de los educadores de la educación especial y los patólogos del habla y lenguaje. Los estudiantes del aprendizaje de servicio participaron en visitas al lugar educacionales, presentaciones de talleres, actividades culturales, e intercambios interprofesionales en Botswana. Los estudiantes completaron encuestas al final del viaje y luego participaron en una entrevista de grupo focal nueve meses después de la terminación del curso de aprendizaje de servicio. Los resultados de un análisis cualitativo del contenido revelaron cinco temas emergentes: $l a$ apertura mental, la expansión de fronteras, la humildad cultural, el desarrollo de habilidades, y la confianza. Se discuten las implicaciones para las colaboraciones interculturales y se consideran las actividades anteriores a la partida, las prácticas educativas de alto impacto, y la confianza estudiantil con respecto al logro de las habilidades profesionales.

Palabras clave: la educación especial, los trastornos comunicativos, la patología del habla y lenguaje, el aprendizaje de servicio internacional, estudiar en el extranjero

Editors' Note: English-to-Spanish translation by Megan J. Myers

Department of World Languages and Cultures

Iowa State University, USA 
For future and current professionals in special education (SPED) and speech-language pathology, developing the interpersonal skills necessary to serve children and families of diverse cultural and linguistic backgrounds is a critical priority. As the diversity of U.S. student populations increases, special educators need to find ways to serve individuals who are at risk for disabilities (Taylor, 2010). Infusing "culturally responsive pedagogical training and practices" is a necessity for all students to reach their full potential (Kea \& Utley, 1998; Taylor, 2010, p. 28). Additionally, professionals need to understand differences in interpersonal and social behaviors, and how disability may be interpreted (Rogers-Adkinson et al., 2003). Engaging in service-learning experiences that focus on intercultural awareness, knowledge, sensitivity, and cultural humility may help address this need (Baecher, 2019; Morley et al., 2019). Baecher (2019) noted that engaging in these experiences intensifies the students' ability to "understand, respect, engage with, and ultimately teach diverse cultural groups" (p. 1). The purpose of this project was to explore the influence of international service-learning on the personal and professional development of future special educators and speech-language pathologists (SLPs).

Although some teacher education programs have begun to incorporate service-learning experiences and activities into their pedagogy (Byker \& Putnam, 2019; Gay, 2010; Olmedo \& Harbon, 2010), there remains limited research on the impact of international service-learning (ISL) programs for special educators and SLPs. SLPs receive their education in communication sciences and disorders (CSD) programs and upon graduation regularly work side by side with SPED teachers in school settings. The SLPs' role is to prevent, assess, diagnose, and treat speech, language, social communication, cognitive-communication, and swallowing disorders in children and adults. Byker and Putnam (2019) noted that study abroad coupled with international teaching experiences have an impact on the development of global competencies, intercultural awareness, culturally responsive pedagogies, and the fostering of empathy. These are all skills needed by special educators and SLPs to create an atmosphere of academic success for the culturally and linguistically diverse students that they serve.

\section{The High-Impact Educational Practices of International Service-Learning}

The current project bridges aspects of cultural immersion and service-learning for the purposes of deepening learning among SPED and CSD students. Cultural immersion is defined as an experiential reality that provides opportunities for participants to directly engage with individuals from cultures different from their own (Ridley et al., 1994; Tomlinson-Clarke \& Clarke, 2010). Cultural engagement is one of the reasons Bringle and Hatcher (2011) suggested that ISL is a pedagogy uniquely designed to prepare higher education students to become engaged "global citizens" (p. 3). They conceptualized ISL as the educational intersection of (a) service-learning, (b) study abroad, and (c) international education (Bringle et al., 2011). Although there are various definitions of service-learning, Bringle and his collaborators are most frequently cited (Felten \& Clayton, 2011). Consequently, their definition guided this project:

A course-based, credit-bearing educational experience in which students (a) participate in an organized service activity that meets identified community needs, and (b) reflect on the service activity in such a way as to gain further understanding of course content, a broader appreciation of the discipline, and an enhanced sense of personal values and civic responsibility. (Bringle \& Hatcher, 2009, p. 38)

ISL deepens learning by exposing students to experiences that may heighten understanding of social problems and inequities they may not otherwise encounter domestically while simultaneously placing students in a cocreated and collaborative learning environment where shared power among all participants is valued (Mitchell, 2008). The consideration of power and privilege is one way that ISL cultivates critical thinking beyond traditional classroom instruction (Hartman \& Kiely, 2014). Reflecting on power dynamics at the personal and structural levels during service-learning activities provides an opportunity for students to develop a more informed and critical consciousness (Hart \& Akhurst, 2017; Sakomoto \& Pitner, 2005).

Faculty frequently integrate service-learning and cultural immersion elements into study abroad courses that are available to students enrolled in higher education institutions. Further, service-learning, 
community-based learning, and study abroad are identified as high-impact educational practices, which may increase positive education results for students from widely varying backgrounds (Kuh, 2008). Evidence to support the initial 10 high-impact practices (HIPs) came from data collected through the National Survey of Student Engagement (NSSE), which suggested that purposeful, systematic, and active learning processes increase rates of student retention and engagement. There are currently 11 HIPs (Kuh, 2008; Watson et al., 2016). For the purposes of this project, the HIPs of collaborative assignments and projects (which promote self-understanding and appreciation of alternative views), diversity/global learning (which increases understanding and appreciation of human differences), service-learning/community based learning (which allows for structured reflection about how classroom learning informs community practice and vice versa), and internships/field experiences (which provide direct experience in a setting typically related to current career interests) are addressed (Kuh et al., 2017).

Although some researchers question whether ISL is distinguished from domestic service-learning in general learning outcomes (Niehaus \& Garcia, 2017), students participating in ISL are more likely to sustain their international engagement and extend their experience as global citizens. Further, in general, servicelearning demonstrates high-impact learning experiences and personal and professional outcomes, including higher-order academic performance, civic engagement, reciprocal collaboration, and personal development (Felten \& Clayton, 2011). Although research indicates that students participating in service-learning performed similarly to nonparticipating students when assessing standard discipline knowledge, students engaged in service-learning activities exceed their peers' performance concerning higher-order, complex tasks (Ash et al., 2005; Felten \& Clayton, 2011). It may be that this deepened learning - the ability to think critically about complex social issues - also lends itself to the sustained civic engagement that servicelearning cultivates. Service-learning participation is credited with enhancing students sustained civic and political engagement, which demonstrates itself through civic efficacy, political interest, community connectedness, and strengthened social solidarity as well as individual life skills (Astin et al., 2000; Eyler, 2011; Felten \& Clayton, 2011). Personal enrichment related to service-learning is connected to various positive attributes, including development in leadership, self-agency and confidence, psychological wellbeing, and self-identity (Astin et al., 2000; Pless et al., 2011). Due to the exposure to diverse situations, peoples, and environments that a student experiences through service-learning, particularly in ISL, a personal appreciation for open-mindedness and deepened empathy may also be developed (Felten \& Clayton, 2011; Stanlick \& Hammond, 2016). Through intersecting cognitive and affective processes, another positive outcome of service-learning is an appreciation for reciprocal collaboration. As Felten and Clayton (2011) succinctly explained, "service-learning encourages students to consider perspectives other than their own and helps them cultivate capacities for making informed judgments" (p. 79). Transformation and social change may occur in the community when students reflect reciprocal collaboration and subordinate their judgment by valuing the contributions of other students, faculty, and community members (Bringle \& Clayton, 2012).

\section{International Service-Learning and Special Education}

Goals, competencies, and outcomes of ISL and cultural immersion study abroad courses in African countries have been documented in several higher education programs, including programs in health sciences and education (Coker \& Majuta, 2015; Nickols et al., 2013; Tomlinson-Clarke \& Clarke, 2010). Yet, the literature is sparse when documenting specific learning experiences in Botswana-and with students studying SPED/CSD, in particular (Heine, 2018). Since service-learning is identified as a highimpact educational practice, it was instructive to explore any nuanced learning or community outcomes associated with students studying SPED/CSD. At the time of the course, Botswana was experiencing an overwhelming number of learners with special educational needs (SEN) in the public schools. Therefore, the teachers needed knowledge and pedagogical skills for teaching learners with special educational needs and exposure to positive practices of inclusion. Even more important, these learners needed prompt screening, identification, diagnosis, and intervention because, with appropriate early detection, intervention, and simple accommodations, they probably would not be deemed special needs. The lack of 
allied professionals to identify and intervene was a major obstacle because the National Central Resource Centre for special education was critically understaffed to meet the needs of all SEN learners in the country.

When examining ISL for preservice educators, Holliday and Brennan (2020) proposed using a transformative learning theoretical perspective and noted that reflection and hands-on tasks during learning can be used to expand an individual's worldview. Areas of exploration may fall under the general categories of student outcomes, partnership outcomes, and program/system outcomes (Blosser \& Means, 2018). Regarding student outcomes, students in education-related disciplines learn the importance of describing and measuring a child's progress in high- and low-demand classroom situations. Partnership outcomes involve creating effective, collaborative partnerships with parents, teachers, and other professionals to develop effective individualized plans and strategies for helping children with communication challenges. Program and system outcomes include making changes and/or improvements within the classroom, school and/or community setting, resulting in more efficient and effective services for students with special needs (Blosser \& Means, 2018).

Another critical area of emphasis for students in education-related service-learning is the ethical standards outlined by SPED and CSD national associations and programs of study-specifically the need for increased cultural humility and linguistic competence. Yomantas (2020) has emphasized the need for culturally responsive teaching in American classrooms and has recommended intensive field experiences where future educators develop a critical consciousness through cyclical action and reflection. Students engaged in service-learning find that their stereotypes are challenged and their cultural awareness is enhanced; discipline-related problem solving and competency are strengthened; and appreciation for, as well as response to, the community experience is increased (Crawford et al., 2017; Hoppes et al., 2005; Knecht \& Fischer, 2015; Kohlbry, 2016; Scott et al., 2005). The development of these personal and professional attributes is relevant to SPED/CSD students as they cultivate clinical skills, learn how to respond empathetically to students/clients, and develop critical-thinking and problem-solving abilities to use in complex educational settings (Heine, 2018).

Being able to practice and cultivate clinical skills in environments where complex social issues exist is highly beneficial to emerging SPED/CSD practitioners (Heine, 2018; Nickols et al., 2013). Although the practical, real-time experience is noted as beneficial, client situations and needs in speech pathology ISL environments are often described as unpredictable and chaotic (Heine, 2018; Pechak et al., 2013). Consequently, preservice training - including role-playing and experiential opportunities - are critical. Adding further complexity and significant learning to ISL experiences for students studying SPED/CSD are cultural considerations (Johnson \& Battalio, 2008). It is not surprising to find that students are initially overwhelmed in ISL learning situations, given the complexity of social issues and cultural immersion. However, it is also documented that students quickly acclimate to these challenges and deepen not only their confidence and self-efficacy but also their clinical practice skills (Heine, 2018; Pechak et al., 2013). Further, in being exposed to challenging situations, students studying SPED/CSD become engaged global citizens - confronting access and quality issues in their future practice (Heine, 2018; Pechak et al., 2013).

Although these findings are overwhelmingly positive, given the considerations of using ISL as a pedagogical approach with students studying SPED/CSD (i.e., ethical clinical practice, cultural responsiveness, instructional expense), additional research is needed. The current study aims to generate understanding of the impact of a cross-cultural and collaborative learning experience in Botswana for undergraduate and graduate students representing the field of SPED/CSD. This study provides insight into participants' intercultural awareness, sensitivity, and cultural humility along with participants' understanding of how children with special needs may be served in international settings. Several strategies to increase cultural competency were embedded within the course to reflect on challenges and successes, including debriefing sessions, reflective journals, and surveys. This analysis will focus on participant surveys completed during the course and a focus group conducted several months after the course, which was used to expand individual learning and reflection. 


\section{Description of the Service-Learning Project}

Considering the minimal research regarding students studying SPED/CSD with ISL experiences, and the importance of providing opportunities to more effectively serve an increasingly diverse population, the purpose of this study was to explore whether ISL influences the personal and professional development of SPED/CSD learners. The significance of evaluating this high-impact learning experience is to assist students in fulfilling the SPED/CSD professional standards that guide the ethical care of patients/clients.

\section{Methods}

A sequential explanatory mixed methods design was used for this research because the authors wanted the participants' experiences to guide the focus group questions. Both qualitative and descriptive quantitative data were gathered, with a priority given to the qualitative data (Ivankova et al., 2006). To explore the depth and meaning of the ISL experience and relevance of ISL to students' global competency and cultural responsivity, a case study approach was utilized (Creswell \& Poth, 2018; Padgett, 2008). Surveys were completed at the end of the experience and a focus group nine months post experience. The results of the surveys were analyzed prior to conducting the focus group and the results guided the development of the focus group questions. Surveys and the focus group interview at different time points provided a more accurate representation of individual and group impact. Completing the surveys while engaged with activities and experiences in Botswana captured the immediate impact of in-country interactions on participants while the focus group completed nine months post trip captured a broader reflection on the impact of the experiences on participants' personal, academic, and professional lives.

The project was approved by the university's Institutional Review Board (1042248-1), and informed consent was obtained from all participants. The purpose and procedures of the study, benefits and risks, right to refuse, privacy, and contact information were explained as part of the informed consent documentation. This study presented no more than minimal risk, participation was voluntary, and names were not published with the results of this study. Completed surveys and focus group transcripts were kept locked at all times and destroyed after three years.

\section{Participants}

Participants in the study consisted of students from a single mid-sized public institution in a rural county in the southern United States. Any undergraduate or graduate student majoring in SPED/CSD could participate in the ISL study abroad course. The students were recruited through presentations in classes and a flyer distributed through e-mail. The course was a joint undergraduate/graduate class titled "International Service-Learning Project - Botswana." The three-credit course was an elective and the graduate students' participation counted as clinical hours. A total of 10 students enrolled in the course and went on the study abroad trip to Botswana. Nine of the students were CSD majors and one was a SPED major.

All 10 participants completed surveys immediately post-trip and were invited to participate in the focus group. Six participants attended the focus group session. Demographics can be found in Table 1. Four participants were current graduate students, one senior undergraduate, and one student who graduated the previous semester; all students were in the CSD program.

\section{Case Context}

Botswana, officially the Republic of Botswana, is a landlocked country in Southern Africa (see Figure 1), with a population of just over 2.3 million. It is rich in both culture and language, with 10 percent of the population living in the capital and largest city, Gaborone. The official language of Botswana is English, although Setswana is widely spoken across the country. The service-learning students stayed at a lodge in Tlokweng, a village located directly adjacent to Gaborone, in the South-East District. 
Table 1

Participant Demographics

\section{Participant Age Education Race Gender Previous Previous Intercultural International Travel Experiences}

\begin{tabular}{|c|c|c|c|c|c|c|}
\hline $1 *$ & 23 & $\begin{array}{l}\text { M.S., 2nd } \\
\text { year }\end{array}$ & White & Female & $\begin{array}{l}\text { Personal Travel - } \\
\text { Jamaica, Bahamas, } \\
\text { Dominican Republic }\end{array}$ & $\begin{array}{l}\text { Participated in a volunteer } \\
\text { service project, formal course } \\
\text { in a language }\end{array}$ \\
\hline & & & & & $\begin{array}{l}\text { Service-learning - } \\
\text { Nicaragua two times }\end{array}$ & \\
\hline $2 *$ & 32 & $\begin{array}{l}\text { M.S., 2nd } \\
\text { year }\end{array}$ & White & Female & $\begin{array}{l}\text { Personal Travel - } \\
\text { Mexico, Canada, St. } \\
\text { Lucia, France, Spain, } \\
\text { Turks \& Caicos }\end{array}$ & $\begin{array}{l}\text { Hosted a foreign language } \\
\text { guest, participated in } \\
\text { volunteer service, personal } \\
\text { interaction in the community } \\
\text { or through social media, } \\
\text { formal course in a language }\end{array}$ \\
\hline $3 *$ & 23 & $\begin{array}{l}\text { M.S., 2nd } \\
\text { year }\end{array}$ & White & Female & $\begin{array}{l}\text { Personal Travel - } \\
\text { British Isles, Mexico, } \\
\text { Canada }\end{array}$ & $\begin{array}{l}\text { Formal course in a language } \\
\text { (Spanish) }\end{array}$ \\
\hline $4 *$ & 23 & $\begin{array}{l}\text { M.S., 2nd } \\
\text { year }\end{array}$ & White & Female & $\begin{array}{l}\text { Personal Travel - } \\
\text { Mexico, Caribbean }\end{array}$ & Formal course in a language \\
\hline $5 *$ & 21 & $\begin{array}{l}\text { B.A., } \\
\text { Senior }\end{array}$ & $\begin{array}{l}\text { African- } \\
\text { American }\end{array}$ & Female & $\begin{array}{l}\text { Volunteer Trip - } \\
\text { Costa Rica } \\
\text { Study Abroad - Spain }\end{array}$ & $\begin{array}{l}\text { Formal course in a language } \\
\text { (Spanish) }\end{array}$ \\
\hline $6^{*}$ & 27 & M.S. & White & Female & $\begin{array}{l}\text { Teach English - } \\
\text { Chile, Spain } \\
\text { Study Abroad - } \\
\text { Mexico }\end{array}$ & $\begin{array}{l}\text { Participated in a home-stay } \\
\text { exchange, a volunteer service } \\
\text { project, personal interaction } \\
\text { in community and through } \\
\text { social media, formal course } \\
\text { in a language }\end{array}$ \\
\hline 7 & 36 & M.S. & White & Male & $\begin{array}{l}\text { Military Service - } \\
\text { Kyrgyzstan, England }\end{array}$ & $\begin{array}{l}\text { Language learning for time in } \\
\text { Kyrgyzstan; formal course in } \\
\text { a language }\end{array}$ \\
\hline 8 & 26 & MAEd. & White & Female & $\begin{array}{l}\text { Volunteer Trip - } \\
\text { Chile, South America }\end{array}$ & $\begin{array}{l}\text { Participated on a farm, } \\
\text { learned and communicated in } \\
\text { Spanish }\end{array}$ \\
\hline 9 & 20 & $\begin{array}{l}\text { B.A., } \\
\text { Senior }\end{array}$ & White & Female & $\begin{array}{l}\text { Personal Travel - } \\
\text { Europe }\end{array}$ & Formal course in a language \\
\hline 10 & 23 & $\begin{array}{l}\text { M.S., 2nd } \\
\text { year }\end{array}$ & White & Female & $\begin{array}{l}\text { No Previous } \\
\text { International Travel }\end{array}$ & Formal course in a language \\
\hline
\end{tabular}


All ISL activities occurred in and around Gaborone. The main aim of the collaboration was to visit schools that had been identified by the Ministry of Basic Education to share ideas with peer special education teachers in those schools and learn from different practices. The collaboration would enable both the participants and teachers to share expertise through discussions and recommendations on a multidisciplinary approach through practice intervention. It would help to guide implementation of intervention, support, strategy, assistive devices, and access arrangements. The collaboration would also provide opportunities for both participants and special education teachers to gather information from one another and to apply it beneficially to both their situations so as to improve delivery.

\section{Figure 1}

Map Showing Location of Botswana

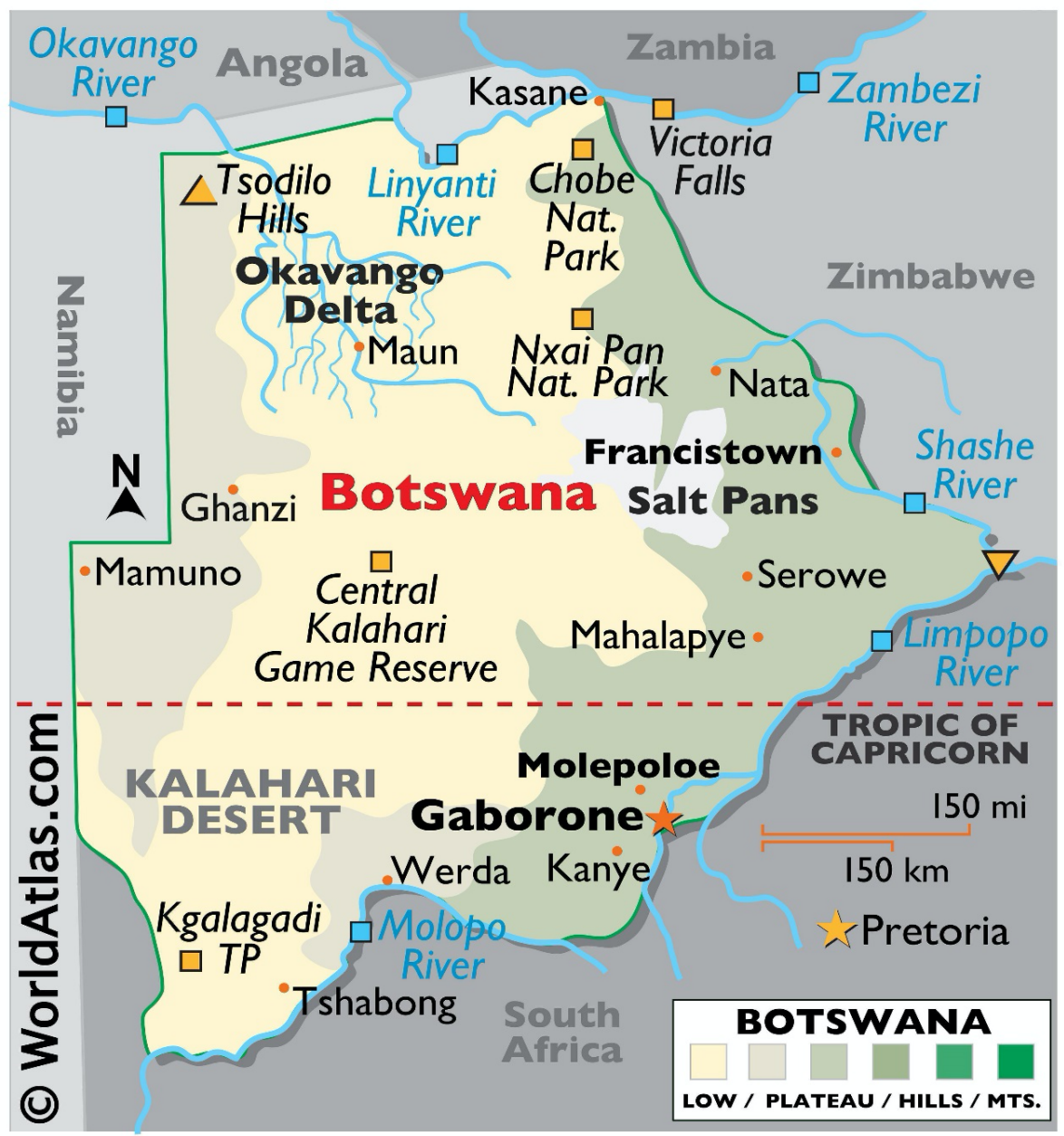

Source: WorldAtlas.com

\section{Partnership}

A partnership effort to address special education along with other areas of need in Botswana has been established between a State located in the southern United States and the Ministry of Education in Botswana through the National Guard State Partnership Program and, more recently, through the State's Department of Military and Veterans Affairs. Principles and procedures of a Memorandum of Understanding signed between the State and the Republic of Botswana include efforts to increase cultural awareness, understanding of shared values, and promotion of common interests through cooperation between various 
agencies, along with sharing of human resources and expertise and providing the opportunity for professional, scholarly, and governmental staff exchanges.

The partnership between the State and the Republic of Botswana is further supported by the State Board of Education. Included in this partnership is a collaboration between the public university involved in this project and the Department of Special Support Services (DSSS, 2013) of the Ministry of Education and Skills Development in Botswana. This collaboration has included reciprocal visits by representatives from each country.

\section{Itinerary}

Ten ISL students and two faculty members participated in the two-week service-learning/study abroad course. The DSSS in Botswana played an integral role in planning details of the itinerary. There were three key features of the project: educational site visits, presentation of workshops, and cultural activities. The participants and teachers collaborated on the curriculum as well as the identification and discussions of curricular activities. Participants observed classes in progress and interacted with the learners, special education teachers, and staff. Also, participants were taught the culture, language, and history of Botswana they learned about the education system of the country and specifically special education.

\section{Educational Site Visits}

Participants visited communities in the urban, peri-urban, and rural areas of the country. They visited public schools and met with nongovernmental organizations that provide education to learners with special educational needs. The educational sites served learners with hearing impairment, autism spectrum disorder, and intellectual disabilities. See Table 2 for descriptions of sites and activities completed.

\section{Workshop Presentations}

Participants planned and presented a full day of workshops at a local public college in Tlokweng. The college offers a three-year diploma in primary education, including special education. Participants presented three 2-hour workshops to 40 attendees, including special educators, faculty, and Tlokweng students. The "Early Intervention" workshop shared developmental milestones for speech and language skills and stressed the importance of early intervention for children with developmental disabilities. The "Augmentative and Alternative Communication" workshop addressed low- and high-tech communication options for children with moderate/severe disabilities and provided examples of communication systems. The "Developing Materials for the Classroom" workshop centered around autism spectrum disorder and structured teaching methodology. Activities included approaches for engineering the classroom environment, use of visual schedules, and creation of shoebox tasks. Due to the desire for activities to be easily incorporated into special needs classrooms, a variety of hands-on learning activities (i.e., visual representation of concepts, demonstrations of teaching strategies, and make and take products) were used in all workshops.

\section{Cultural Activities}

Participants stayed at a game lodge in Madikwe, South Africa, and observed more than 27 species of animals, including the big five game animals (lion, leopard, rhinoceros, elephant, and Cape buffalo). Other outings during the experience included shopping, dining, and a half-day drive through the Gaborone Game Reserve, a small national reserve inside the city of Gaborone. Participants learned Botswana traditions, history, and language through interactions with children, teachers, and administrators and a visit to Matsieng footprints, engraved petroglyphs dating back between 3,000 and 10,000 years. Traditional food was provided; it included seswaa (traditional meat dish), mopane worms, and pap or porridge. The group attended a farewell dinner at a popular craft store courtyard with local fare, song, and dance. Special educators and administrators accompanied participants to meals and cultural activities for further sharing of information related to language, traditions, history, and the educational system. 
Table 2

Educational Site Visits

\begin{tabular}{|c|c|c|c|}
\hline $\begin{array}{l}\text { Educational } \\
\text { Site }\end{array}$ & Location & Site Description & Activities Completed \\
\hline $\begin{array}{l}\text { Central } \\
\text { Resource } \\
\text { Center (CRC) }\end{array}$ & Tlokweng & $\begin{array}{l}\text { Established in } 1990 \text { to assess } \\
\text { children with disabilities for } \\
\text { placement in special needs } \\
\text { classrooms and to provide } \\
\text { counsel to parents on their } \\
\text { child's disability and resulting } \\
\text { placement decisions. }\end{array}$ & $\begin{array}{l}\text { Formal introductions, overview of } \\
\text { work assignments; assisted SLP in } \\
\text { completing assessments with four } \\
\text { children and their families; participated } \\
\text { in producing written reports }\end{array}$ \\
\hline $\begin{array}{l}\text { Center for } \\
\text { Deaf } \\
\text { Education }\end{array}$ & Ramotswa & $\begin{array}{l}\text { One of two residential } \\
\text { facilities serving children with } \\
\text { hearing impairment in the } \\
\text { country, with } 100 \text { children } \\
\text { residing at the school plus } 18 \\
\text { academic staff. }\end{array}$ & $\begin{array}{l}\text { Formal introductions, tour of facility, } \\
\text { speech and language assessments of } 12 \\
\text { children; feedback session at the end of } \\
\text { the day with classroom teachers and } \\
\text { administration. }\end{array}$ \\
\hline $\begin{array}{l}\text { Ithuteng } \\
\text { Primary } \\
\text { School }\end{array}$ & Gaborone & $\begin{array}{l}\text { A governmental primary } \\
\text { school with a Special } \\
\text { Education unit. Approximately } \\
20 \text { children attended the unit } \\
\text { with } 3 \text { classrooms and } 3 \\
\text { teachers. Ages ranged from } \\
\text { early primary to adult, with a } \\
\text { variety of disabilities. }\end{array}$ & $\begin{array}{l}\text { Formal introductions, tour of school; } 5 \\
\text { speech and language assessments and } \\
\text { teacher feedback session. Results of } \\
\text { assessments were written by students } \\
\text { with recommendations including a } \\
\text { variety of learning and communication } \\
\text { strategies. }\end{array}$ \\
\hline $\begin{array}{l}\text { Camphill } \\
\text { Community } \\
\text { Trust }\end{array}$ & Otse & $\begin{array}{l}\text { A nongovernmental (NGO) } \\
\text { residential facility established } \\
\text { in Botswana } 40 \text { years ago to } \\
\text { serve children with special } \\
\text { needs; currently serving } \\
\text { people from primary school } \\
\text { through adulthood. }\end{array}$ & $\begin{array}{l}\text { Students toured the site and engaged in } \\
\text { a formal meeting with administration. }\end{array}$ \\
\hline $\begin{array}{l}\text { Princess } \\
\text { Marina } \\
\text { Hospital }\end{array}$ & Gaborone & $\begin{array}{l}\text { The largest referral hospital in } \\
\text { Botswana, with } 530 \text { inpatient } \\
\text { beds and facilities for speech } \\
\text { language therapy, physical } \\
\text { therapy, and occupational } \\
\text { therapy. }\end{array}$ & $\begin{array}{l}\text { Completion of } 6 \text { speech and language } \\
\text { treatment sessions. Students toured the } \\
\text { hospital, observed the newborn unit, } \\
\text { and walked through the children and } \\
\text { adult wards. }\end{array}$ \\
\hline
\end{tabular}

\section{Measures and Data Collection}

\section{Sensitivity to Context}

There are many methods to demonstrate sensitivity to context, including familiarity with relevant theoretical and practice literature, empirical data, sociocultural setting, participants' perspectives, and 
ethical issues (Yardley, 2000). The primary researcher was familiar with the theoretical and practice literature related to discipline-specific clinical skills in SPED/CSD. Further, the primary researcher was intimately connected with the sociocultural context related to SPED/CSD. All researchers adhered to the highest ethical conduct throughout the research process. In addition to fulfilling requirements of human subjects review, the researchers regularly communicated with their collaborators in Botswana, and one collaborator is a coauthor of this article. Researchers were also sensitive to power differentials among researchers, community collaborators, and student participants.

\section{Student Survey}

All 10 participants completed surveys upon their return to the United States. The first and second author developed the survey, and the other authors and an additional expert researcher validated the survey. The questions were chosen to gather information about participant interactions and skill learning and to provide recommendations for future projects. The question format was similar for each group and contained three Likert Scale questions ( $5=$ strongly agree; $4=$ agree; $3=$ neither agree nor disagree; $2=$ disagree; $1=$ strongly disagree) and three open-ended questions.

\section{Focus Group Interview}

The focus group interview took place approximately nine months after the study abroad course was completed in a conference room on the university campus. Five of the participants attended in person and one participant used Skype. The instructor/primary author and facilitator/secondary author were present. The focus group session included an overview and purpose of the session, informed consent, introductions, and ground rules.

The interview guide consisted of four open-ended questions and allowed for follow-up and probing questions (Table 3). Each question for the focus group was chosen through group discussion among all five researchers after a review of the survey results. The first question led to self-reflection and reflection on how the experience impacted each student, either personally or professionally, or both. The second question was a compare-and-contrast question that required respondents to engage in critical thinking about their learning experiences in two different countries. It also related to an academic paper required for the course. The third question encouraged respondents to identify their most impactful experience and its personal significance. The fourth question related specifically to the university's common read, The Bright Continent: Breaking Rules and Making Change in Modern Africa by Dayo (Olopade, 2015). Specifically, the researchers were informed by Olopade's (2015) critical discussion of the outside-in approach that too frequently accompanies Western-influenced aid and development activities in African nations. More directly, Olopade (2015) referred to such white-savior interventions by a locally known acronym, SWEDOW-or "stuff we don't want" (p. 53). SWEDOW is the physical manifestation of outside helpers who think they best understand community needs and opportunities in the absence of considering the knowledge and expertise of local people. In essence, African communities become the recipients of SWEDOW, instead of having Westerners partnering with the communities to build on existing assets and resources. This question also came up during the site visit at the Center for Deaf Education when one of the teachers stated, "When the white man comes, it rains." The students were uncomfortable with this question; more discussion surrounding the comment and the content of the book ensued, and this question was added to the focus group as a follow-up. The session lasted approximately one hour, was audio-recorded, and was transcribed verbatim.

Five researchers independently coded the surveys and transcripts using conventional qualitative content analysis (Hsieh \& Shannon, 2005). Conventional content analysis helps to identify, analyze, and report patterns or themes within data and is an appropriate method to describe emotional reactions without the researchers' use of preconceived categories (Kondracki et al., 2002). As Braun and Clarke (2006) noted, this type of analysis is widely used and offers an accessible and flexible approach to analyzing qualitative data. 
Table 3

Focus Group Questions

1. Can you tell me how studying abroad impacted you?

2. What is the largest cultural difference you have seen between the two countries?

3. Tell me a story about one of your experiences in Africa. Why is this important to you?

4. Tell me what this phrase means to you: "When the white man comes, it rains."

Data analysis started with each researcher reading the data several times to understand the data as a whole, with no a priori assumptions (Manimozhi \& Srinivasan, 2018). Researchers read the data, looking for repeated phrases and concepts, then summarized first impressions and initial analysis. Impressions became initial codes, which were then grouped into relevant clusters (Manimozhi \& Srinivasan, 2018). Researchers discussed codes and clusters found independently and reached consensus on five main themes that emerged.

To demonstrate transparency and coherence, the researchers established a fit between theory and method and addressed reflexivity (Yardley, 2000). The primary researcher maintained field notes to illustrate the research process and provide transparency of subjectivity and bias. The field notes were used to establish any bias and remove the bias from the data interpretation. In addition, the researchers included extensive excerpts of transcribed text in tandem with their interpretations for the audience to follow the interpretative process of articulating the ISL experience. Trustworthiness was ensured through independent coding by all researchers, member checks, and peer review (Creswell \& Creswell, 2018; Gibbs, 2007). Member checks involved the researchers sharing the initial results with participants and asking them to examine the findings relative to their own experiences to ensure that the findings were accurate and plausible (Pitney, 2001).

\section{Findings}

\section{Student Survey}

A student survey assessed overall program success for the participants. In Table 4, mean scores ranged from 4.6 to 4.9 on the Likert Scale. Participants indicated that they enjoyed the opportunity to interact with SLPs and special educators from another country $(M=4.9)$, that the experience provided them with new skills and strategies that may impact their work with special needs children in the future $(M=4.9)$, and that they recommend this experience to other students $(M=4.6)$. Comments focused on educational site visits, challenges, and recommendations for future trips. 
Table 4

Botswana: Student Survey

Survey Question

1. I enjoyed having the opportunity to interact with speechlanguage pathologist and special educators from another country

2. This international service-learning opportunity provided me with some new skills and strategies that will directly impact how I work with special needs students in the future

3. I would recommend this experience to other students studying communication disorders and special education

\section{Mean Score $(N=10)$}

4.9 (9 Strongly Agree, 1 Agree)

4.9 (9 Strongly Agree, 1 Agree)

4.6 (6 Strongly Agree, 4 Agree)

\section{Comments}

4. What did you feel was the best part of this experience?

5. What would you change about this experience?
- Going to the different locations to get a feel for many different settings

- Being able to be hands on with treatment and assessments

- Being able to experience the safari

- Experiencing another culture/country

- Learning to be flexible

- Seeing new disorders I hadn't seen during my clinical placements

- Being able to learn and think on your feet in a place you are not familiar with

- I feel the best part of this experience was having to be flexible and having to use what few materials we had when doing assessments and treatment. I think both of those aspects will make me a better clinician

- Spending more time at the $\mathrm{CRC}$

- Break up the workshops into different days

- Having a day to catch up and rest

- Adding a little more history or culture of Botswana into the trip

- More cultural activities need to be included

- Timing of activities; use time more wisely

- Have a workshop focused on Autism

- Full workshop on parent training

- Literacy, strategies for parents

- Social stories

- Classroom arrangements
6. What additional areas related to communication disorders and special education do you think should be addressed in future works for Botswana special educators? 


\section{Focus Group}

The focus group revealed five emerging themes: (1) open-mindedness, (2) boundary spanning, (3) cultural humility, (4) skill development, and (5) confidence (see Table 5). Identified themes provide important insight into the impact of this ISL program for CSD/SPED students. The five themes and their definitions are not to be considered in isolation as there is some overlap among them. They provide a roadmap to analyze and document growth in participants' preparedness for working in diverse professional settings.

\section{Table 5}

Themes and Definitions

Theme Definition

Open-mindedness

Open-mindedness is generally defined as being willing to rethink an idea or concept despite having a previously formed viewpoint. Being open-minded requires autonomy and has been shown to contribute to the effectiveness of diverse teams (Hare, 2003; Mitchell et al., 2012; Taylor, 2017).

Boundary-spanning Boundary-spanning acknowledges the need for acceptance of differing perspectives but further addresses the ability to cross over disciplinary lines, to learn from one another through both self-awareness and awareness of others in public or private employment sectors (Muñoz \& Jeris, 2005; Needham et al., 2017, Weerts \& Sandmann, 2010; Williams, 2002). Boundary-spanning also includes competencies such as building interpersonal relationships, fostering trust, and managing power relationships (Williams, 2002).

Cultural humility Cultural humility is defined as having two main characteristics, intrapersonal (an awareness of one's own limitations in regard to one's own cultural worldview and one's ability to understand others' worldview) and interpersonal (other-oriented in relation to the other person's cultural background and experiences, marked by respect and lack of superiority) (Hook \& Davis, 2019). Cultural humility is identified as a need for preprofessional skill development in both CSD and SPED programs of study.

Skill Development CSD programs follow the Knowledge and Skill Acquisition Standards, which delineate specialized outcomes for learning skills in evaluating and treating children and adults with communication disabilities. Additional skill areas include interaction and personal qualities, and oral and written forms of communication. SPED programs follow Initial Preparation Standards as outlined by the Council for Exceptional Children, with program requirements of providing sufficient opportunities to develop and demonstrate appropriate pedagogical skills, including extensive field experiences and clinical practice.

Confidence Confidence is an encompassing theme that takes into account the many activities experienced by the participants. Results from previous higher education studies engaging college students in diverse experiences have shown increased academic self-confidence, social agency, and critical thinking when engaged in positive interactions with diverse peers (Laird, 2005; Roksa et al., 2017). 


\section{Open-Mindedness}

Participants found that they needed to be open-minded and aware of their preconceived notions and stereotypes. One participant provided an example of a workshop that she and another participant gave to the SPED teachers at Tlokweng College. The participants had a script and thought they knew what the teachers needed; however, when they started the workshop, they realized that the teachers would benefit from something else. They had to get rid of the preconceived notions and listen to the Motswana teachers. Another participant had a similar experience where she realized she had biases and needed to observe and listen to understand how she could best serve the people in Botswana. Many participants self-reflected during the experience and realized they were taught as much, if not more, than they taught. One participant stated:

I think we've learned a lot more, like life lesson wise from them and being there. ... It was more collaboration, like when the teachers during our presentation were like okay, well, we had scenarios for them but then they were like, okay, well, my student is going through this. So, it was I do this, what do you suggest? It wasn't like we're American and we are telling you to do this.

Additionally, they felt that the Motswana people had culture-related preconceived notions about them. They reflected on a time where they went to a remote school and the students were all signing to each other, "They're white, they're white." One participant made a link to what was happening in their own country and concerns about what may be preconceived about them, given a U.S. president who espoused isolationist policies and perspectives:

I was embarrassed just being a white American because I don't want to be associated with Trump. ... Just because I'm white, I don't want to be thought of like that.

Many of the other participants agreed with this comment. Furthermore, the participants felt that it helped them realize that they had preconceived notions. One participant commented:

I think it's [learning about different cultures] especially important now because the news and media like to feed you certain things about different cultures so you experience it first-hand. Especially like traveling to Africa for me, because you always see the commercials of starving kids; so, a lot of people think that's all of Africa and that's only what's in Africa. So, it was nice to actually be there and experience it.

One of the participants was African American. Reflecting on the meaning of the learning experience for her, she noted an ancestral connection to the community as well as being challenged by competing ideas she held:

Like wow, my ancestors are from here, this is so crazy. And then I think seeing the elephant that was the moment, because at first, I was like yeah, I'm in another country but I don't really feel like I'm in this other country because we are staying at this inn and a really nice hotel in South Africa and then we were out there and I saw that and I was like, ya know, elephants don't roam around in the United States. And I was like, this is Africa.

The feelings relating to open-mindedness were very personal for each student, with expressed linkages to family dynamics and/or previous experiences.

\section{Boundary Spanning}

Participants largely felt that the experience gave them perspective on the world and other cultures. They had to learn how to interact with people who spoke a different language and who were from a different culture. When discussing cultural differences, the participants all agreed that punctuality and perception of time were different. But they did recognize that learning this was valuable. One participant stated that she learned to be more flexible about being on time and changing a lesson plan when the Botswana educators indicated that they preferred something different. 
The participants bonded with one another. Most participants did not know one another before the experience, and they learned how to build trust and interact with among themselves. Many thought that this experience would help them as professionals, deepening their interpersonal skills when interacting with patients and other professionals. For example, one participant stated:

I think that it kind of helped me with my patience. I'm a very impatient person; so, it helped me just by having limited resources or schedules not lining up and helped me to kind of calm down when it comes to being impatient.

Participants consistently noted the need for greater flexibility, especially with time management, and learning to be patient with their peers and with those whom they met in the country.

\section{Cultural Humility}

Many participants had moving stories about developing cultural humility that helped them learn about the culture of the people from Botswana. Participants stated that they had preconceived notions about the culture. One shared that she recognized the need to keep an open mind and not go into the experience with any biases and preconceived ideas about Botswana and Africa. Every participant nodded in agreement with this and acknowledged the importance of listening to the people they were serving. For example, another participant said:

We went in wanting to learn from them not so much you need do this, you need to do this. Obviously, we came in with ideas of how we could help but it wasn't our ideas were superior it was wanting them to also teach us.

Not only did the students deepen their cultural humility, but they also had a greater sense of modesty in general. A participant shared an experience that developed her introspection about significant life challenges that may affect a client/patient. She shared that one of the patients was an 8-year-old boy diagnosed with cerebral palsy and recently had his feeding tube removed. His mother had to carry him to the hospital. Their challenges did not end there:

When we were done with the eval and sitting their chatting with her and asking if she was going to go back to her village. Her mom had died the day before; so, she said no - that she had to travel to that village. I don't know, it was some long travel time, and I was like "wow, you came and got your son therapy," and I was just so shocked. I feel like I'll always remember that when working with patients.

Another humbling learning experience concerned possessions. One of the men working the night shift at the inn was looking at the participant's camera because he was also a photographer. She shared:

There was a picture of my old house on it, and they were blown away that I had a house, like, myself. And that for me was pretty humbling and huge because I was like oh, I liked that house, I didn't love it but, and then I was like oh wow, that's my house, I should be thankful for it.

As future SLPs and educators, participants expressed sensitivity for understanding differences in the patients whom they worked with at the educational sites. They related their observations to previous clinical or personal experiences with disability.

\section{Skill Development}

Most participants had a moderate amount of patient interaction; the second-year graduate students had two years of supervised clinical experience in both child and adult settings with varying disabilities and the undergraduates did not have any. The Botswana experience helped them realize how much they actually knew and that they could be effective with minimal equipment. For example, one graduate student participant reflected on an experience at a primary school where she and another participant were supposed to assess children, and the only materials available were paper and pencils. The participants worked with a 
child with Down syndrome, and it was a notable skill development experience because they are used to having games, materials, and fun toys that are interactive to get the patients engaged. They did not have high technology, but they were still able to provide excellent care with paper, crayons, rocks, sticks, or pencils. One participant stated that the most significant learning was that she did not need the most advanced technology because she had the skills to do therapy with whatever was available.

A different participant had a similar experience while working with a 23-year-old male with cerebral palsy. The Botswana teachers told her that the patient could not do many things. She created a communication board and had the student point to things. She commented:

It shocked us with what he knew. So, it was amazing, and I felt good and proud that we were able to come up with this board out of a piece of paper. We gave ideas to them, and they were super receptive of it.

This went beyond developing hands-on skills. Participants shared an experience from an outpatient hospital with a police officer who suffered from a traumatic brain injury. The participant stated:

He forgot his language, and I think both of us were about to cry because it was so neat to see him come in with one of his police officer friends and see him try so hard. It made us realize that it's about making a connection with your patient. The more connection you have with a patient, the more they will buy into the therapy. It was just a neat experience.

Participants used the skills they learned in Africa in their current education and practice. Two participants discussed how they used what they did in Africa during their master's project. They learned methods during the experience, which gave them the foundation for exploring new ideas and increased their competence. Similarly, another example of skill development came from a participant who did not initially think that her experiences were going to be directly applicable to her job. She said:

I came back to North Carolina and thought I'm probably not going to be able to use a lot of this stuff. But first thing, I got a referral for a little girl that had just gotten adopted from an orphanage in China and she hadn't been exposed to any English. ... So, it was interesting using what I had learned over there to transfer here.

Participants showed evidence of constructive learning as well. One participant stated that in classes since the trip, she would think of how to apply to Botswana the material she was learning. During classes, she would think of how she could use the skills in Botswana, how the particular class example would not work within the settings in Botswana, and how she could have changed what she did with the students in order to better help them. While participants were at different points in their educational careers, they each expressed that skills or strategies that they learned in Botswana were continuing to influence new learning and experiences.

\section{Confidence}

Participants felt that their confidence increased overall and would help them in the future. For example, one participant shared that her confidence as a professional improved because she did speech therapy in a different country with limited resources. She often thought to herself, "I can do this; I did it in Botswana."

Participants also found that their confidence in dealing with people, working with limited resources, and surmounting language barriers increased. The participants overwhelmingly felt that their ISL/study abroad experience increased their confidence in their capabilities to be professionals and helped them socialize to the profession.

Additionally, participants saw the confidence increase in each other. One of the participants, who was an undergraduate, seemed less confident to the other participants. However, they had to complete a parent interview near the end of the experience, and she led the interview and did a fantastic job. The others commented on how she did not second-guess herself and it was a great interview. She herself stated: 
I am undergrad while everyone else is in grad school; so, I was really nervous. I'd say don't secondguess yourself because I was super nervous, and it wasn't that bad actually, like being over there applying stuff that I had learned in classes.

Participants consistently expressed their increased feeling of confidence after returning from the trip, especially within academic or professional activities.

\section{Discussion and Implications}

Findings suggest it is beneficial for SPED/CSD students to engage in ISL. This is a contribution to the current knowledge base as there is minimal research with this specific student population as participants in ISL, in general, and in Botswana, in particular. Overall, participants expressed that their experience was beneficial, both professionally and personally. Findings showed the participants felt that the ISL experience provided them with new skills and strategies that would directly impact their future work in the field. The focus group revealed additional insights into how the ISL experience affected participant growth in (1) open-mindedness, (2) boundary spanning, (3) cultural humility, (4) skill development, and (5) confidence. These findings support prior research on ISL (Crawford et al., 2017; Heine, 2018; Johnson \& Battalio, 2008, Morley et al., 2019; \& Pechak et al., 2013).

The high-impact practices associated with the project appear to contribute to both the personal and professional development of the students (Kuh et al., 2017). This finding is a relevant contribution for other instructors of SPED/CSD as they consider the most effective curriculum design to teach ethical clinicalpractice skills, empathetic and culturally humble relationship-building with clients/patients and the diverse communities in which they reside, and strengthen their ability to be innovative and creative problem-solvers in complex healthcare situations with diverse clients. Further, recent research has also indicated the ability to deepen critical learning by scaffolding additional high-impact practices into ISL. Bringle (2017) suggested complementing ISL with four other HIPs: (1) service-learning, (2) study abroad, (3) research, and (4) internships. For the purposes of this and similar projects, it may be beneficial to integrate intentional community-based participatory action research (Padgett, 2008), which may enhance reciprocal and collaborative approaches with the local community and provide internship opportunities abroad.

One of the main purposes of this project was to expose SPED/CSD students to culturally diverse clients and situations through an ISL experience. Some of the challenges noted in the student survey concerned cultural issues. For example, participant feedback on Survey Question 5 (What would you change about this experience?) indicated frustration with time management and timing of activities. In Botswana, the arrival time for a meeting is more flexible than in the United States, and importance is placed on taking time for personal interaction and communication. In the focus group, participants expressed that being flexible and patient would help as future professionals.

Coker and Majuta (2015), who engaged in an international experience teaching a group counseling course at an institution of higher learning in Botswana, found that respect is important to group dynamics, with older group members providing mature feedback, social support, guidance, cultural value, and credibility. Collectivism and giving advice also need to be appreciated because of their importance in communities like those in Botswana. Some successful strategies to work through cross-cultural challenges were identified. They include regular debriefing sessions to share concerns and highlight successes; journaling; peer supervision; and learning as much as possible about the host country prior to travel, especially its language and customs.

In addition, Coker and Majuta (2015) identified important elements of preparation activities, including discussion of cultural content with students for their ISL participation. Yet other research indicates that predeparture activities should expand beyond cultural content overviews to include role-playing and handson experiential activities (Taylor et al., 2017). Team building during the predeparture phase of the course may have helped to prepare participants more effectively to assign roles and develop strategies in working together (Tuckman \& Jensen, 1977). This expanded preparation seems particularly essential to SPED/CSD students, who encountered challenging health- and/or education-related situations and needed to work collaboratively with one another and with others to achieve their goals. 
The participants were initially challenged by complex issues and constrained resources encountered in the ISL setting, which affirms prior research findings (Taylor et al., 2017). Kiely (2005) conceptualized such service-learning situations as "disorientating dilemmas" (p. 7). Although these situations are described as creating disruptions and dissonance for students, it is often where confidence builds and transformative learning occurs in ISL settings (Hartman \& Kiely, 2014; Taylor et al., 2017). The ISL experience provided the learning environment to connect textbook knowledge with applied clinical practice. Further, it appeared that this uncomfortable nexus underscored the overall purpose of this project: preparing SPED/CSD students to respond more effectively to complex issues and diverse client populations.

The findings for the theme of confidence align with a finding from a study by Nickols et al. (2013) that students' self-confidence increased as a result of ISL. It was noted that personal development related to adaptability and maturity are frequently attributed to ISL experiences (Astin et al., 2000; Stanlick \& Hammond, 2016). For this course, student confidence appeared to increase over time and was frequently expressed during the focus group discussion. Possessing confidence is critical for future educators and SLPs as it will enhance planning abilities, increase resiliency and persistence, and help them be better models for their students.

As the partnership between Botswana and the university has evolved, emphasis has been placed on creating a reciprocal relationship with the sharing of ideas and strategies and learning from one another. During the focus group session, students discussed that, while they were working with others and helping their peer educators, they felt that they were being taught so much more. Being cognizant of who benefits from service-learning experiences, as well as maintaining a balance, is critical to the success of the current project and also to developing deeper relationships and creating opportunities for educators in both countries (Hartman \& Kiely, 2014; Meens, 2014). It is also worth reflecting on disorienting dilemmas here: When students are properly prepared during their preservice experience, they can quickly acclimate to disruptive environments, and respond with complex and innovative thinking, resulting in their being more responsive and reciprocal collaborators (Bringle \& Clayton, 2012; Felten \& Clayton, 2011).

To summarize, the themes outlined above show that ISL experiences for students studying SPED/CSD can have a direct impact on their future work as educators in American schools. While this ISL experience was only two weeks in duration, the intensity of the hands-on activities with educators in the host country and cyclical reflection appeared to be transformative. SPED/CSD students regularly engage in domestic service-learning activities through clinical practicum and student teaching experiences; however, this ISL experience added greater levels of interaction and collaboration with educators and children from a diverse ethnic group, with the heightened tension of living and working in a cross-cultural and under-resourced region.

\section{Limitations}

A limitation of this study was the small sample size and relative homogeneity of the participant group. This is common for this type of qualitative study, however, where the aim is to provide rich and thick descriptions of the students' experiences rather than generalizing to other populations. Several of the students who took part in the ISL experience were unavailable to participate in the focus group because of graduation from their respective programs and because they live and work in other parts of the state.

It may have been helpful to engage in systematic gathering of student data prior to participation in the ISL project-specifically, in areas related to content, skills, and attitudes. Having this pre-/postcomparative data would have helped the researchers delve even deeper into what was gained and learned by the participants. Another consideration for future research would be to incorporate in the research design data collected through direct and indirect measures, which could better address questions related to student learning and development 


\section{Conclusion}

ISL experiences with collaborative partners in other countries who share similar professional goals, such as improving services for individuals with disabilities, can influence the personal and professional growth of future special educators and SLPs. Specifically, ISL has an effect on the development of the interpersonal skills necessary to serve children and families of diverse cultural and linguistic backgrounds. There could be far-reaching benefits as participants apply what they learned during ISL, in their clinical preparation and during interactions with students, families, and other professionals. High-impact practices like ISL help in teaching broad skills such as problem solving, critical thinking, and cross-cultural communication.

Additionally, engaging in preservice preparation, which incorporates collaborative skill development, knowledge and reflection of power dynamics, and strategies to deal with uncomfortable situations, should be considered. Programs in CSD/SPED may benefit from including this content in course and/or program objectives. This experience led to cross-cultural relationships, collaboration, and communication between the participants and professionals in Botswana, which led to transformative educational experiences and is positively impacting services for children with disabilities in both the United States and Botswana.

\section{References}

Ash, S. L., Clayton, P. H., \& Atkinson, M. P. (2005). Integrating reflection and assessment to capture and improve student learning. Michigan Journal of Community Service Learning, 11(2), 49-60. http://hdl.handle.net/2027/spo.3239521.0011.204

Astin, A. W., Vogelgesang, L. J., Ikeda, E. K., \& Yee, J. A. (2000). How service learning affects students.Higher Education Research Institute, University of California, Los Angeles.

Baecher, L. (2019). Study abroad in teacher education. Global Education Review, 6(3), 1-3.

Blosser, J., \& Means, J. (2018). School programs in speech-language pathology: Organization and delivery. Plural Publishing.

Braun, V., \& Clarke, V. (2006). Using thematic analysis in psychology. Qualitative research in psychology, 3(2), 77-101. https://doi.org/10.1191/1478088706qp063oa

Bringle, R. G., \& Clayton, P. H. (2012). Civic education through service learning: What, how, and why? In L. McIlrath, A. Lyons, \& R. Munck (Eds.), Higher education and civic engagement; Comparative perspectives (pp. 101-124). Palgrave Macmillan. https://doi.org/10.1057/9781137074829 7

Bringle, R. G., \& Hatcher, J. A. (2009). Innovative practices in service-learning and curricular engagement. New Directions for Higher Education, 147, 37-46. https://doi.org/10.1002/he.356

Bringle, R. G., \& Hatcher, J. A.(2011). International service learning. In R. G. Bringle, J. A. Hatcher, \& S. G. Jones (Eds.), International service learning: Conceptual frameworks and research (pp. 328). Stylus Publishing.

Byker, E. J., \& Putman, S. M. (2019). Catalyzing cultural and global competencies: Engaging preservice teachers in study abroad to expand the agency of citizenship. Journal of Studies in International Education, 23(1), 84-105. https://doi.org/10.1177/1028315318814559

Coker, A. D., \& Majuta, A. R. (2015). Teaching group counseling in Botswana: Two U.S.trained counselors discuss experiences and share cultural considerations for practice. The Journal for Specialists in Group Work, 40(1), 102-116. https://doi.org/10.1080/01933922.2014.992506 
Crawford, E., Caine, A., Hunter, L., Hill, A. E., Mandrusiak, A., Anemaat, L., Dunwoodie, R., Fagan, A., \& Quinlan, T. (2017). Service learning in developing countries: Student outcomes including personal successes, seeing the world in new ways, and developing as health professionals. Journal of Interprofessional Education \& Practice, 9, 74-81. https://doi.org/10.1016/j.xjep.2017.08.006

Creswell, J., \& Creswell, J. (2018). Research design: Qualitative, quantitative, and mixed methods approaches (5th ed.). SAGE.

Creswell, J., \& Poth, C. (2018). Qualitative inquiry and research design: Choosing among five approaches (4th ed.).SAGE.

Department of Special Support Services (DSSS). (2013). Project on assessment of learners with special needs. Government of Botswana.

Eyler, J. (2011). What international service learning research can learn from research on service learning. In R. G. Bringle, J. A. Hatcher, and S. G. Jones (Eds.), International service learning: Conceptual frameworks and research (pp. 225-242). Stylus Publishing.

Felten, P., \& Clayton, P. H. (2011). Service-learning. New Directions for Teaching and Learning, 128, 75-84. https://doi.org/10.1002/t1.470

Gay, G. (2010). Acting on beliefs in teacher education for cultural diversity. Journal of Teacher Education, 61(1-2), 143-152. https://doi.org/10.1177\%2F0022487109347320

Gibbs, G. (2007). Analyzing qualitative data. In U. Flick (Ed.). The SAGE Qualitative Research Kit. SAGE. https://doi.org/10.4135/9781849208574

Hare, W. (2003). The ideal of open-mindedness and its place in education. Journal of Thought, 38(2), 310.

Hart, A., \& Akhurst, J. (2017). Community-based learning and critical community psychology practice: Conducive and corrosive aspects. Journal of Community \& Applied Social Psychology, 27(1), 315. https://doi.org/10.1002/casp.2287

Hartman, E., \& Kiely, R. (2014). Pushing boundaries: Introduction to the global service-learning special section. Michigan Journal of Community Service Learning, 21(1), 55-63.

Heine, C. (2018). Students as partners in a service-learning program: Speech pathology students in Cambodia. Partnerships: A Journal of Service-Learning and Civic Engagement, 9(1), 18-30.

Holliday, E., \& Brennan, S. (2020). Building a pathway to prepare globally competent teachers. In L. Baecher (Ed.), Study abroad for pre-and in-service teachers: Transformative learning on a global scale (pp. 3-17). Routledge.

Hook, J. N., \& Davis, D. E. (2019). Cultural humility: Introduction to the special issue. Journal of Psychology and Theology, 47(2), 71-75. https://doi.org/10.1177/0091647119842410

Hoppes, S., Bender, D., \& DeGrace, B. W. (2005). Service learning is a perfect fit for occupational and physical therapy education. Journal of Allied Health, 34(1), 47-50.

Hsieh, H., \& Shannon, S. (2005). Three approaches to qualitative content analysis. Qualitative Health Research, 15(9), 1277-1288. https://doi.org/10.1177/1049732305276687

Ivankova, N. V., Creswell, J. W., \& Stick, S. L. (2006). Using mixed-methods sequential explanatory design: From theory to practice. Field Methods, 18(1), 3-20. https://doi.org/10.1177\%2F1525822X05282260 
Johnson, L. E., \& Battalio, R. (2008). Expanding the boundaries of special education preservice teachers: The impact of a six-week special education study abroad program. International Journal of Special Education, 23(3), 90-100.

Kea, C. D., \& Utley, C. A. (1998). To teach me is to know me. The Journal of Special Education, 32(1), 44-47. https://doi.org/10.1177/002246699803200108

Kiely, R. (2005). A transformative learning model for service-learning: A longitudinal case study. Michigan Journal of Community Service Learning, 12(1), 5-22.

Knecht, J. G., \& Fischer, B. (2015). Undergraduate nursing students' experience of service-learning: A phenomenological study. Journal of Nursing Education, 54(7), 378-384. https://doi.org/10.3928/01484834-20150617-04

Kohlbry, P. W. (2016). The impact of international service-learning on nursing students' cultural competency. Journal of Nursing Scholarship, 48(3), 303-311. https://doi.org/10.1111/jnu.12209

Kondracki, N. L., Wellman, N. S., \& Amundson, D. R. (2002). Content analysis: Review of methods and their applications in nutrition education. Journal of Nutrition Education and Behavior, 34(4), 224-230.

Kuh, G. D. (2008). High-impact educational practices: What they are, who has access to them, and why they matter. Association of American Colleges and Universities.

Kuh, G., O’Donnell, K., \& Schneider, C. G. (2017). HIPs at ten. Change: The Magazine of Higher Learning, 49(5), 8-16. https://doi.org/10.1080/00091383.2017.1366805

Laird, T. F. N. (2005). College students' experiences with diversity and their effects on academic selfconfidence, social agency, and disposition toward critical thinking. Research in higher education, 46(4), 365-387. https://doi.org/10.1007/s11162-005-2966-1

Manimozhi, F., \& Srinivasan, P. (2018). A meta synthesis of content analysis approaches. American Journal of Educational Research, 6(6), 632-637.

Meens, D. E. (2014). Democratic and social justice goals in service-learning evaluation: Contemporary challenges and conceptual resources. Michigan Journal of Community Service Learning, 21(1), 41-54.

Mitchell, T. D. (2008). Traditional vs. critical service-learning: Engaging the literature to differentiate two models. Michigan Journal of Community Service Learning, 14(2), 50-65.

Mitchell, R., Parker, V., \& Giles, M. (2012). Open-mindedness in diverse team performance: Investigating a three-way interaction. The International Journal of Human Resource Management, 23(17), 3652-3672. https://doi.org/10.1080/09585192.2012.654807

Morley, A., Braun, A. M., Rohrer, L., \& Lamb, D. (2019). Study abroad for preservice teachers. Global Education Review, 6(3), 4-29.

Muñoz, K., \& Jeris, L. (2005). Learning to be interdisciplinary: An action research approach to boundary spanning. Health Education Journal, 64(1), 5-12. https://doi.org/10.1177/001789690506400102

Needham, C., Mastracci, S., \& Mangan, C. (2017). The emotional labour of boundary spanning. Journal of Integrated Care, 25(4), 288-300. https://doi.org/10.1108/JICA-04-2017-0008

Nickols, S., Rothenberg, N., Moshi, L., \& Tetloff, M. (2013). International service-learning: Students' personal challenges and intercultural competence. Journal of Higher Education Outreach and Engagement, 17(4), 97-124. 
Niehaus, E. K. \& Garcia, C. E. (2017). Does location really matter? Exploring the role of place in domestic and international service-learning experiences. International Journal of Research on Service-Learning and Community Engagement, 5(1), 99-118.

Olmedo, I., \& Harbon, L. (2010). Broadening our sights: Internationalizing teacher education for a global arena. Teaching Education, 21(1), 75-88. https://doi.org/10.1080/10476210903466992

Olopade, D. (2015). The bright continent: Breaking rules and making change in modern Africa. First Mariner Books.

Padgett, D. K. (2008). Qualitative methods in social work research (2nd ed.). SAGE.

Pechak, C., Gonzalez, E., Summers, C., \& Capshaw, S. (2013). Interprofessional education: A pilot study of rehabilitation sciences students participating in interdisciplinary international service-learning. Journal of Allied Health, 42(2), e61-e66.

Pitney, W. A. (2001). Qualitative inquiry in athletic training: Principles, possibilities, and promises. Journal of Athletic Training, 36(2), 185-189.

Pless, N. M., Maak, T., \& Stahl, G. K. (2011). Developing responsible leaders through international service-learning programs: The Ulysses experience. Academy of Management Learning \& Education, 10(2), 237-260. https://doi.org/10.1007/978-94-007-3995-6

Ridley, C., Mendoza, D., Kanitz, B., Angermeier, L., \& Zenk, R. (1994). Cultural sensitivity in multicultural counseling: A perceptual schema model. Journal of Counseling Psychology, 41(2), 125-136. https://doi.org/10.1037/0022-0167.41.2.125

Rogers-Adkinson, D. L., Ochoa, T. A., \& Delgado, B. (2003). Developing cross-cultural competence: Serving families of children with significant developmental needs. Focus on Autism and Other Developmental Disabilities, 18(1), 4-8. https://doi.org/10.1177/108835760301800102

Roksa, J., Kilgo, C. A., Trolian, T. L., Pascarella, E. T., Blaich, C., \& Wise, K. S. (2017). Engaging with diversity: How positive and negative diversity interactions influence students' cognitive outcomes. The Journal of Higher Education, 88(3), 297-322.

https://doi.org/10.1080/00221546.2016.1271690

Sakamoto, I., \& Pitner, R. (2005). Use of critical consciousness in anti-oppressive social work practice: Disentangling power dynamics at personal and structural levels. The British Journal of Social Work, 35(4), 435-452.

Scott, S. B., Harrison, A. D., Baker, T., \& Wills, J. D. (2005). Interdisciplinary community partnership for health professional students: A service-learning approach. Journal of Allied Health, 34(1), 3135.

Stanlick, S. E. \& Hammond, T. C. (2016). Service-learning and undergraduates: Exploring connections between ambiguity tolerance, empathy, and motivation in an overseas service trip. International Journal of Research on Service-Learning and Community Engagement, 4(1), 273-289.

Taylor, R. W. (2010). The role of teacher education programs in creating culturally competent teachers: A moral imperative for ensuring the academic success of diverse student populations. Multicultural Education, 17(3), 24-28.

Taylor, R. M. (2017). Education for autonomy and open-mindedness in diverse societies. Educational Philosophy and Theory, 49(14), 1326-1337. https://doi.org/10.1080/00131857.2017.1278673

Tomlinson-Clarke, S. M., \& Clarke, D. (2010). Culturally focused community-centered service-learning: An international cultural immersion experience. Journal of Multicultural Counseling and Development, 38(3), 166-175. https://doi.org/10.1002/j.2161-1912.2010.tb00124.x 
Tuckman, B. W., \& Jensen, M. A. C. (1977). Stages of small-group development revisited. Group \& Organization Management, 2(4), 419-427. https://doi.org/10.1177/105960117700200404

Watson, C. E., Kuh, G. D., Rhodes, T., Light, T. P., \& Chen, H. L. (2016). ePortfolios - The eleventh high impact practice. International Journal of ePortfolio, 6(2), 65-69. http://www.theijep.com/pdf/IJEP254.pdf

Weerts, D. J., \& Sandmann, L. R. (2010). Community engagement and boundary-spanning roles at research universities. Journal of Higher Education, 81(6), 702-727. https://doi.org/10.1080/00221546.2010.11779075

Williams, P. (2002). The competent boundary spanner. Public Administration, 80(1), 103124. https://doi.org/10.1111/1467-9299.00296

Yardley, L. (2000). Dilemmas in qualitative health research. Psychology and Health, 15, 215-228. https://doi.org/10.1162/DAED a 00040

Yomantas, E. L. (2020). Experiential education as a precursor to culturally responsive teaching. Study Abroad for Pre- and In-Service Teachers, 99-111. In L. Baecher (Ed.), Study abroad for pre-and in-service teachers: Transformative learning on a global scale (pp. 99-111). Routledge.

\begin{abstract}
About the Authors
Amy Rose is an associate professor in the Department of Communication Sciences and Disorders at Western Carolina University.
\end{abstract}

Melissa Snyder is an associate professor at Western Carolina University.

Amy Murphy-Nugen is an associate professor and graduate program director in the Department of Social Work, College of Health and Human Sciences, at Western Carolina University.

Gayle Maddox is a professor of health education at Western Carolina University.

Carol Isaac MacKusick is a former faculty member at Western Carolina University and is now working as an adult nurse practitioner for HCA in a rural setting.

Bontle Molefe is the former director of the Special Support Services Department, Ministry of Basic Education, Botswana; chairperson of the Botswana Society for the Deaf, and a member of SAALED.

Correspondence concerning this article should be addressed to Amy Rose at ajrose@wcu.edu. 